AJIE - Asian Journal of Innovation and Entrepreneurship

(e-ISSN: 2477- 0574 ; p-ISSN: 2477-3824)

Vol. 02, No. 02, May 2017

\title{
ANALISIS PENGARUH KREDIT MACET DAN KECUKUPAN LIKUIDITAS TERHADAP EFISIENSI BIAYA OPERASIONAL BANK UMUM SYARIAH DI INDONESIA
}

\author{
${ }^{1}$ Taudlikhul Afkar \\ Fakultas Ekonomi,Prodi Akuntansi, Universitas PGRI Adi Buana Surabaya \\ E-mail : afkar@unipasby.ac.id
}

\begin{abstract}
Expense efficiency is one of the ways to gain a bigger profit. Profit, as a component of financial performance measures, indicates the management capability in handling finance issues, such as operational expenses. This study discusses the operational expenses efficiencies related to bad credit or financing problems and liquidity adequacy. The results of this study show that Non Performing Financing (NPF) significantly affects the operational cost efficiency of Islamic Banks in Indonesia as much as 40.2\%. It means that in the event of Non Performing Financing (NPF), operational expenses is expected to be inefficient because a significant part of the expenses would be allocated for backup or to erase productive assets collectability. Meanwhile, the liquidity adequacy does not significantly affect the efficiency of the operational expenses. Simultaneously, both of these variables have an important role in the financial performance since they give an overview of their role in the operating expenses efficiency by $20.8 \%$.
\end{abstract}

Keywords: Non Performing Financing, Liquidity, Operational Expenses

\begin{abstract}
ABSTRAK
Efisiensi biaya merupakan salah satu upaya untuk mendapatkan laba yang lebih besar. Laba merupakan salah satu komponen ukuran kinerja keuangan yang menunjukkan kemampuan manajemen dalam mengelola keuangan salah satunya biaya operasional. Penelitian ini membahas mengenai efisiensi biaya operasional yang dipengaruhi oleh kredit macet atau pembiayaan bermasalah dan kecukupan likuiditas. Hasil penelitian ini menunjukan bahwa kredit macet berpengaruh signifikan terhadap efisiensi biaya operasional Bank Umum Syariah di Indonesia sebesar 40,2\% artinya ketika terjadi kredit macet maka biaya operasional menjadi tidak efisien karena banyak biaya yang dikeluarkan untuk cadangan maupun penghapusan kolektabilitas aktiva produktif. Sedangakan kecukupan likuiditas tidak berpengaruh secara signifikan terhadap efisiensi biaya operasional. Secara simultan kedua variabel tersebut memiliki peran yang penting dalam kinerja keuangan yang mana kedua variabel tersebut memberikan gambaran peranannya dalam efisiensi biaya operasional sebesar $20.8 \%$.
\end{abstract}

Kata Kunci : Kredit Macet, Likuiditas, Biaya Operasional 


\section{PENDAHULUAN}

\section{Latar Belakang}

Bank syariah di Indonesia mulai berdiri pada tahun 1991 yang bernama Bank Muamalat Indonesia. Perkembangan Bank Syariah di Indonesia sampai saat ini sudah lebih banyak, dimana Bank Umum Syariah sudah ada 11 sedangkan Unit Usaha Syariah juga sudah lebih banyak. Sistem dual banking di Indonesia menyebabkan persaingan dalam usaha penghimpunan dana dan penyaluran dana semakin kompetitif. Persaingan yang kompetitif tentunya akan menimbulkan biaya-biaya operasional maupun non operasional yang lebih kompetitif pula. Hal ini dapat dikarenakan dalam usaha pengimpunan dana dan penyaluran dana.

Kebutuhan terhadap dana bagi pengusaha kecil maupun pengusaha besar dalam mengembangkan usahanya menjadi peluang bagi lembaga keuangan bank maupun non bank untuk berkompetisi memberikan pembiayaan. Meningkatnya kegiatan perekonomian menjadikan bank berlomba-lomba meberikan pelayanan jasa keuangan yang terbaik agar dapat kepercayaan dari masyarakat. Semakin kompetitif usaha jasa keuangan dalam perbankan menjadikan usaha ini berisiko tinggi karena adanya kemungkinan tidak dapat ditagih kembali atau kredit macet yang akan mengakibatkan bank menjadi bangkrut seperti pada kasus likuidasi bank tahun 1999.

Risiko besar menjadi momok bagi usaha karena berhubungan dengan analisis dan tingkat kepercayaan. Penyaluran dana melalui pembiayaan atau kredit kepada nasabah telah diberikan aturan-aturan dengan adanya batas maksimum pemberian kredit (BMPK) sehingga tingkat kecukupan likuiditas harus diperhatikan. Signifikansi pembiayaan yang diberikan kepada nasabah adalah untuk mendapatkan pendapatan yang lebih besar (Afkar, 2012) karena dari pembiayaan yang diberikan akan mendapatkan bagian seperti bagi hasil ataupun pendapatan dari kemitraan.

Risiko penyaluran dana dalam bentuk kredit atau pembiayaan merupakan risiko yang harus ditanggung oleh pihak bank ketika nasabah tidak mampu membayar kembali pinjaman beserta tambahan sehingga pendapatan dari pembiyaan menjadi macet. Permintaan nasabah dan analisis internal menentukan besar kecilnya pembiayaan yang diberikan sehingga diperlukan perhatian khusus dalam mengalokasikan pembiayaan. Risiko penyaluran pembiayaan ini berkaitan dengan kecukupan likuiditas bank karena dengan adanya tingkat likuiditas yang memadai maka bank dapat memberikan pembiayaan dengan baik.

Tingkat stabilitas keuangan bank syariah pada saat terjadinya krisis keuangan pada tahun 2008 menunjukkan pada hal yang baik karena stabilitas keuangan terlihat stabil meskipun ada krisis keuangan akan tetapi ada risiko yang dapat meneyebabkan kebangkrutan bank yaitu adanya kredit macet dan banyaknya metode untuk mendapatkan pendapatan ketika bank syariah mengelola keuangannya (Rahji, 2012). Penelitian Hasan dan Dridi (2010); Abedifar, dkk (2013); Olson dan Zoubi (2008); Beck, dkk (2013); Bourkhis dan Nabi (2013) ketika terjadi krisis keuangan tingkat likuiditas dan profitabilitas mengalami penurunan, pada saat bersamaan ketidakmampuan nasabah membayar kembali pinjamannya menyebabkan risiko kredit macet mengalami kenaikan.

Kegiatan usaha penghimpunan dan penyaluran dana oleh perbankan pastinya 
menimbulkan biaya yang tidak sedikit.Tingginya biaya operasional menunjukkan efisiensi dalam pengelolaannya rendah (Ambo, 2013). Stabilitas bank kemungkinan pendapatan dan biaya operasional juga akan stabil, sebaliknya ketika mengalami permasalahan karena faktor internal maupun eksternal akan berbeda hasilnya. Hasil penelitian (Bahtiar, 2003) menunjukkan bahwa Non Performing Loan tidak memiliki pengaruh yang signifikan terhadap biaya operasional dan pendapatan operasional (BOPO).

Kecukupan likuiditas bank syariah dalam memberikan pembiayaan terkadang melampaui lebih dari $100 \%$ sehingga berisiko terhadap daya tahan likuiditasnya (Afkar, 2015). Pembiayaan bermasalah atau kredit macet ditunjukkan rasio non performing finance (NPF). Pembiayaan yang bermasalah ini pada akhirnya akan mengarah pada fluktuasi laba yang diperoleh karena pembiayaan merupakan kegiatan usaha terbesar dalam perbankan (Judisseno, 2005). Penelitian (Angbazo, 1997) menunjukkan bahwa kecukupan likuiditas yang ditunjukkan dengan Loan to Deposit Ratio (LDR) memiliki pengaruh yang signifikan terhadap biaya operasional dan pendapatan operasional.

Perubahan stabilitas keuangan perbankan inilah yang menimbulkan ketertarikan untuk diteliti mengenai pengaruh dari kredit macet atau pembiayaan yang bermasalah serta kecukupan tingkat likuiditas bank syariah yang terkadang melampaui hingga diatas $100 \%$ sehingga ada kemungkinan membuat kemampuan bank syariah dalam mengelola keuangan untuk efisiensi biaya operasional dan pendapatan operasional menjadi lebih baik atau sebaliknya dalam usaha yang kompetitif dengan bank konvensional.

\section{Rumusan Masalah}

1. Apakah efisiensi biaya operasional Bank Umum Syariah di Indonesia dipengaruhi oleh kredit macet?

2. Apakah efisiensi biaya operasional Bank Umum Syariah di Indonesia dipengaruhi oleh kecukupan likuiditas?

3. Apakah efisiensi biaya operasional Bank Umum Syariah di Indonesia secara simultan dipengaruhi kredit macet dan kecukupan likuiditas?

4. Variabel manakah yang paling dominan berpengaruh terhadap efisiensi biaya operasional Bank Umum Syariah di Indonesia?

\section{Tujuan Penelitian}

1. Untuk mengetahui pengaruh kredit macet terhadap efisiensi biaya operasional Bank Umum Syariah di Indonesia.

2. Untuk mengetahui pengaruh kecukupan likuiditas terhadap efisiensi biaya operasional Bank Umum Syariah di Indonesia.

3. Untuk mengetahui pengaruh kredit macet dan kecukupan likuiditas secara simultan terhadap efisiensi biaya operasional Bank Umum Syariah di Indonesia.

4. Untuk mengetahui variabel manakah yang paling dominan berpengaruh terhadap efisiensi biaya operasional Bank Umum Syariah di Indonesia.

\section{Manfaat Penelitian}

1. Untuk perkembangan ilmu pengetahuan tentang Bank Syariah yang ada di Indonesia khusunya yang berhubungan dengan variabel-variabel yang ada dalam penelitian ini. 
2. Untuk referensi studi lebih lanjut dengan kajian yang lebih luas untuk mendapatkan hasil yang lebih sempurna serta dapat dijadikan acuan bagi peneliti lain dalam menemukan model kerangka konseptual yang baru dengan memadukan, memodifikasi serta menambah variabel serta diharapkan dapat menemukan teoriteori baru.

\section{KAJIAN TEORI}

\section{Kredit Macet}

Daya tahan bank syariah salah satunya dapat dilihat dari ketahanan kredit atau pembiayaan yang diberikan dengan mengelola pembiayaan bermasalah dibawah ambang batas (Afkar 2015). Kredit merupakan kegiatan usaha yang paling besar yang dilakukan oleh perbankan (Judisseno, 2005). Kredit yang bermasalah merupakan salah satu bentuk risiko yang harus dihadapi oleh lembaga keuangan baik bank maupun lembaga pembiayaan lainnya. Kolektabilitas bank dalam mengumpulkan kembali atas pembiayaan atau kredit yang telah diberikan dapat dilihat dari perbandingan antara pengembalian yang diterima dengan pembiayaan yang telah diberikan dengan melihat persentase Non Performing Loan untuk bank konvensional dan Non Performing Finance pada bank syariah (Judisseno, 2005). Kredit yang bermasalah dikategorikan kurang lancar, diragukan, dan macet terhadap seluruh pembiayaan yang telah dikeluarkan (Juddiseno, 2005)

Kredit macet berkaitan dengan kemampuan nasabah dalam membayar kembali pinjamannya. Ketika nasabah benar-benar tidak mampu mengembalikan pinjaman beserta bunga atau nisbahnya maka penerimaan kembali dari pembiayan yang telah diberikan dapat dikatakan macet sehingga mempengaruhi kemapuan bank dalam mengelola keuangan. Kredit bermasalah (Bank Indonesia, 2010) dikategorikan sebagai kolektabilitas aktiva produktif yang kriterianya diragukan atau macet.

Bank Indonesia mewajibkan adanya cadangan penghapusan atas pembiayaan yang bermasalah untuk menjaga kontinuitas dan keamanan keuangan milik deposan (Bank Indonesia, 2010). Besarnya pembiayaan bermasalah dapat mengakibatkan dana cadangan untuk penghapusan pembiayaan bermasalah juga besar sehingga terjadi penurunan profitabilitas bank pada umumnya (Bank Indonesia, 2010). Pengukuran profitabilitas bank dapat dilihat dari Return On Asset (ROA) (Sutojo, 2008). Biaya yang dicadangkan akan menjadi lebih besar ketika harus mencadangkan penghapusan pembiayaan bermasalah.

\section{Kecukupan Likuiditas}

Likuiditas yang mencukupi memberikan gambaran umum atau salah satu unsur kesehatan bank syariah sehingga masyarakat dapat memberikan penilaian terhadap kelangsungan jalannya usaha perbankan. Likuiditas merupakan kemampuan bank dalam menyediakan dana serta mengubah aset dalam bentuk likuid untuk memenuhi kewajiban keuangannya.

Loan to Deposits Ratio (LDR)
merupakan indikator yang dapat
digunakan untuk mengukur tingkat
likuiditas bank terutama dalam bank
konvensional, sedangkan bank syariah
tidak ada istilah kredit (loan), akan tetapi
pembiayaan (financing), sehingga yang
digunakan adalah Financing to Deposits
Ratio (FDR) (Muhammad, 2005).
merupakan indikator yang dapat digunakan untuk mengukur tingkat likuiditas bank terutama dalam bank konvensional, sedangkan bank syariah tidak ada istilah kredit (loan), akan tetapi pembiayaan (financing), sehingga yang Ratio (FDR) (Muhammad, 2005). 
Likuiditas perlu dijaga kecukupannya demi menjaga kepercayaan masyarakat, oleh karena itu untuk menjaga likuiditas diperlukan aset yang cepat untuk dapat diubah ke dalam bentuk kas agar dapat memenuhi kewajiban pada deposan dalam waktu yang singkat (Afkar, 2015). Risiko likuiditas adalah bahwa ketika bank menyalurkan dana nasabah melalui pembiayaan yang diberikan dengan jumlah yang tinggi secara prosentase, maka bank syariah dihadapkan pada kemungkinan adanya penarikan secara bersamaan oleh nasabah yang akan berakibat pada kesulitan dana yang likuid sementara dana jangka pendek yang dihasilkan tidak sebesar bank konvensional melalui surat berharga (Afkar, 2015).

Likuiditas perbankan terkait dengan kemampuannya dalam menyediakan dana dalam jangka pendek yang dapat digunakan untuk menyalurkan dana melalui pembiayaan atau kredit. Kesempatan untuk dapat memberikan pembiayaan merupakan harapan mendapatkan keuntungan atau laba. Tingkat likuiditas bank rendah maka menunjukkan adanya idle money (dana menganggur) dengan kata lain bank tidak mampu mengelola keuangan dengan baik (Kuncoro, 2002) sehingga kesempatan untuk mendapatkan laba menjadi menurun. Disisi lain biaya operasional dapat dikatakan dalam jumlah yang relatif tetap, maka jika pendapatan yang diperoleh tidak relatif tetap atau lebih besar maka akan terjadi penurunan profitabilitas.

\section{Efisiensi Biaya}

Salah satu tujuan perusahaan adalah untuk menjaga kelangsungan usahanya dengan mendapatkan keuntungan atau laba secara kontinyu. Laba yang maksimal dapat diperoleh dengan cara salah satunya adalah efisiensi biaya dengan pendapatan yang tinggi. Biaya operasional pendapatan operasional (BOPO) dapat digunakan untuk pengukuran efisiensi biaya dalam usaha perbankan (Ambo, 2013). Biaya operasional merupakan biaya yang dikeluarkan untuk aktivitas usaha. Penurunan profitabilitas salah satunya disebabkan biaya operasional yang besar selanjutnya akan mengurangi laba sebelum pajak (Dendawijaya, 2005).

Sisi lain dari efisiensi biaya operasional adalah adanya persaingan usaha yang sangat kompetitif yang ditambah lagi dengan adanya sistem dual banking yang ada di Indonesia yaitu bank konvensional dan bank syariah. Kompleksitas usaha bank syariah memerlukan biaya yang tidak sedikit pula karena selain untuk biaya operasional pada saat melakukan aktivitas transaksi keuangan juga untuk biaya dalam rangka pengembangan pengetahuan sumber daya manusia agar lebih kompetitif. Pengelolaan biaya operasional ini akan berdampak pada kemampuan bank syariah dalam usahanya mendapatkan laba, pengelolaan biaya operasional dengan pendapatan operasional merupakan salah satu ukuran yang digunakan untuk mengukur efisiensi biaya (Afkar, 2015).

Rasio biaya operasional pendapatan operasional (BOPO) sering dikatakan sebagai rasio efisiensi untuk mengukur kemampuan manajemen bank dalam mengelola biaya operasional terhadap pendapatan operasional yang ada. Kecil rasio ini menunjukkan semakin efisien biaya operasional yang dikeluarkan bank sehingga bank semakin kecil mengalami masalah (Siamat, 2005). Pengelolaan biaya operasional dan pendapatan operasional terkait dengan risiko operasional, dimana risiko operasional terjadi karena adanya 
ketidakpastian mengenai usaha bank, seperti adanya kemungkinan kerugian dari operasi ketika terjadi penurunan keuntungan yang dipengaruhi oleh struktur biaya operasional bank dan kemungkinan terjadinnya kegagalan atas jasa-jasa dan produk-produk baru yang ditawarkan.

\section{Penelitian Terdahulu}

Penelitian terdahulu digunakan untuk memberikan gambaran awal tentang variabel yang teliti dalam penelitian ini sehingga dapat diketahui hasil penelitian sebelumnya. Hasil penelitian sebelumnya dapat dijadikan perbadingan atau membangun hasil penelitian atas temuantemuan yang baru atau hanya membuktikan melalui alat analisis yang sesuai.

Penelitian yang dilakukan oleh Afkar (2012) menunjukkan bahwa pembiayaan yang diberikan berpengaruh signifikan terhadap dana pihak ketiga dimana biaya dalam operasional pembiayaan diimbangi dengan penghimpunan dana pihak ketiga. Afkar (2014) Pembiayaan bermasalah (NPF) berpengaruh signifikan terhadap likuiditas dimana pembiayaan bermasalah menjadikan tingkat likuiditas berkurang karena pasokan dana dari likuiditas menurun. Afkar (2015) Risiko kredit berpengaruh signifikan terhadap kecukupan modal dimana kredit yang diberikan berisiko terhadap kecukupan modal yang dimiliki karena kredit yang diberikan berisiko bermasalah dalam hal pengembaliannya.

Hasil Penelitian Listyorini (2012) CAMEL mempengaruhi kinerja perusahaan perbankan yang Go Publik dengan menggunakan indiator analisis CAR, PPAP, DER, BOPO, LDR). Harun (2016) ROA tidak dipengaruhi oleh Rasio CAR dan NIM sedangkan LDR, BOPO,
NPL berpengaruh signifikan terhadap ROA. Dewi, dkk (2015) menunjukkan pengaruh negatif dari BOPO dan NPL terhadap profitabilitas pengaruh positif terhadap profitabilitas ditunjukkan oleh NIM dan LDR. Aini (2013) CAR berpengaruh signifikan positif terhadap perubahan laba, sedangkan LDR dan NPL berpengaruh positif tetapi tidak signifikan terhadap perubahan laba. NIM, BOPO, dan KAP berpengaruh signifikan secara negatif terhadap perubahan laba.

\section{METODE PENELITIAN}

\section{Rancangan Penelitian}

Penelitian ini menggunakan
pendekatan kuantitatif $\begin{array}{r}\text { explanatory } \\ \text { research dengan tujuan menjelaskan }\end{array}$
pengaruh antar variabel melalui pengujian
hipotesis yang digunakan untuk
membuktikan pengaruh antar variabel
yang digunakan dalam penelitian ini
dengan menggunakan uji statistik.

\section{Populasi dan Sampel}

Populasi dalam penelitian ini adalah seluruh Bank Umum Syariah di Indonesia dengan jumlah Bank Syariah sebanyak 11 hingga tahun 2016. Pengambilan sampel dalam penelitian ini dilakukan dengan Purposive Sampling berdasarkan laporan keuangan gabungan yang diolah oleh Bank Indonesia kinerja Bank Umum Syariah, selanjutnya menentukan unit analisisnya yang sesuai dengan tujuan dan kebutuhan penelitian sehingga didapatkan sampel yang representatif.

\section{Definisi Operasional Variabel}

Setiap penelitian yang menggunakan variabel perlu dijelaskan secara definitif dan indikator apa saja yang digunakan untuk mengukur atau mendeskripsikan variabel yang ada dalam penelitian. 
Variabel dalam penelitian ini terdapat 2(dua) variabel bebas yang terdiri dari Kredit Macet $\left(\mathrm{X}_{1}\right)$ dan Kecukupan
Likuiditas $\left(\mathrm{X}_{2}\right)$, sedangkan Variabel terikatnya terdapat satu yaitu Efisiensi Biaya Operasional (Y).

Tabel 3.1

Definisi Operasional Variabel Penelitian

\begin{tabular}{|c|c|c|}
\hline Variabel & Definisi & Indikator \\
\hline $\begin{array}{l}\text { Kredit } \text { Macet } \\
\left(\mathrm{X}_{1}\right)\end{array}$ & $\begin{array}{l}\text { Merupakan pembiayaan yang } \\
\text { belum/tidak dapat diterima } \\
\text { pelunasannya pada periode } \\
\text { akuntansi berjalan }\end{array}$ & $\begin{array}{l}\text { Non Performing Finance } \\
(\mathrm{NPF}) \\
\mathrm{NPF}=\frac{\text { Pembiayaan Bermasalah }}{\text { Aktiva Produktif }} \times 100\end{array}$ \\
\hline $\begin{array}{l}\text { Kecukupan } \\
\text { Likuiditas }\left(\mathrm{X}_{2}\right)\end{array}$ & $\begin{array}{l}\text { Merupakan kemampuan bank } \\
\text { mengubah asset dalam bentuk } \\
\text { yang likuid (kas) dalam waktu } \\
\text { yang relatif cepat dengan tujuan } \\
\text { untuk menyediakan pembayaran } \\
\text { kewajibannya }\end{array}$ & $\begin{array}{l}\text { Financing to Deposits Ratio } \\
\text { (FDR) } \\
\mathrm{FDR}=\frac{\text { Total pembiayaan }}{\text { jumlah DPK }} \times 100\end{array}$ \\
\hline $\begin{array}{l}\text { Efisiensi Biaya } \\
\text { Operasional } \\
\text { (Y) }\end{array}$ & $\begin{array}{l}\text { Merupakan kemampuan } \\
\text { mengelola keuangan dengan } \\
\text { tujuan mendapatkan laba yang } \\
\text { optimal dengan efisiensi biaya }\end{array}$ & $\begin{array}{l}\text { Biaya Operasional Pendapatan } \\
\text { Operasional (BOPO) } \\
\text { BOPO } \\
\frac{\text { Biaya Operasional }}{\text { Pendapatan Operasional }} \times 100\end{array}$ \\
\hline
\end{tabular}

\section{Kerangka Konseptual}

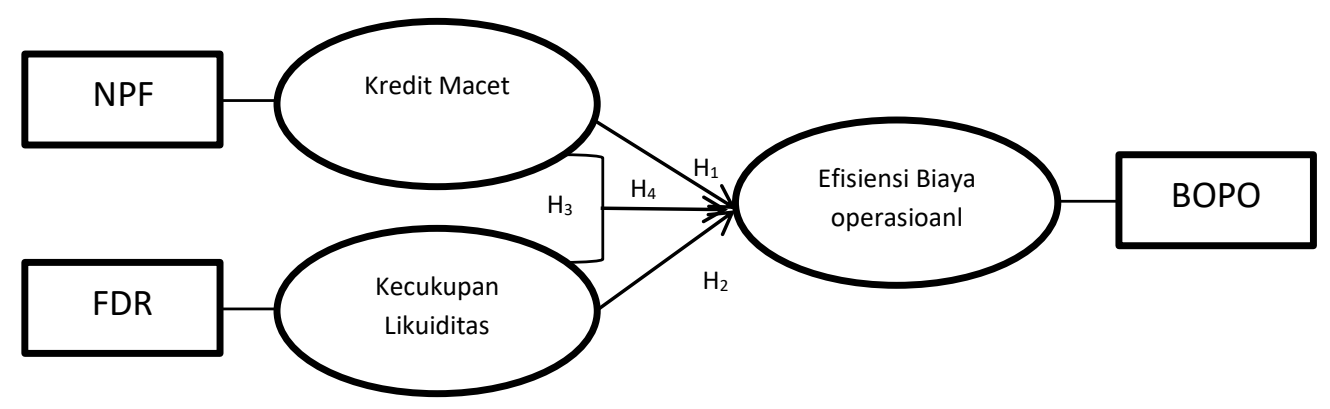

Gambar 3.1

\section{Kerangka Konseptual}

Konsep penelitian ini untuk mengetahui pengaruh dari variabel kredit macet dan kecukupan likuiditas terhadap efisiensi biaya operasional Bank Umum Syariah di Indonesia. Variabel kredit macet diukur dengan rasio Non Performing Finance (NPF), variabel
Kecukupan Likuiditas diukur dengan rasio Financing to Deposits Ratio (FDR), sedangkan Efisiensi Biaya Operasional diukur dengan menggunakan rasio Biaya Operasional Pendapatan Operasional (BOPO). Berdasarkan koerangka konseptual yang diturunkan dari landasan 
teori didapatkan 4(empat) hipotesis terkait pengaruh dari variabel dalam penelitian ini.

\section{Kerangka Berpikir}

Kerangka berpikir ini dimulai dengan studi teoritis dan studi empirik dari beberapa artikel ilmiah yang kemudian muncul permasalahan sesuai dengan teori dan empiris. Permasalahan tersebut dihubungkan dengan teori yang digunakan kemudian ditetapkan hipotesis sebagai bentuk penegasan awal dalam penelitian ini. Selanjutnya berdasarkan hipotesis tersebut dikumpulkan data yang kemudian di uji dengan perhitungan statistik yang sesuai dan hasilnya dianalisis secara deskriptif untuk menjelaskan pengaruh antar variabel yang ada dalam penelitian ini. Pada akhirnya hasil penelitian digunakan untuk membangun teori atau mendukung teori yang ada dan dengan temuan-temuan yang baru dapat dijadikan perbandingan dengan temuan-temuan sebelumnya.

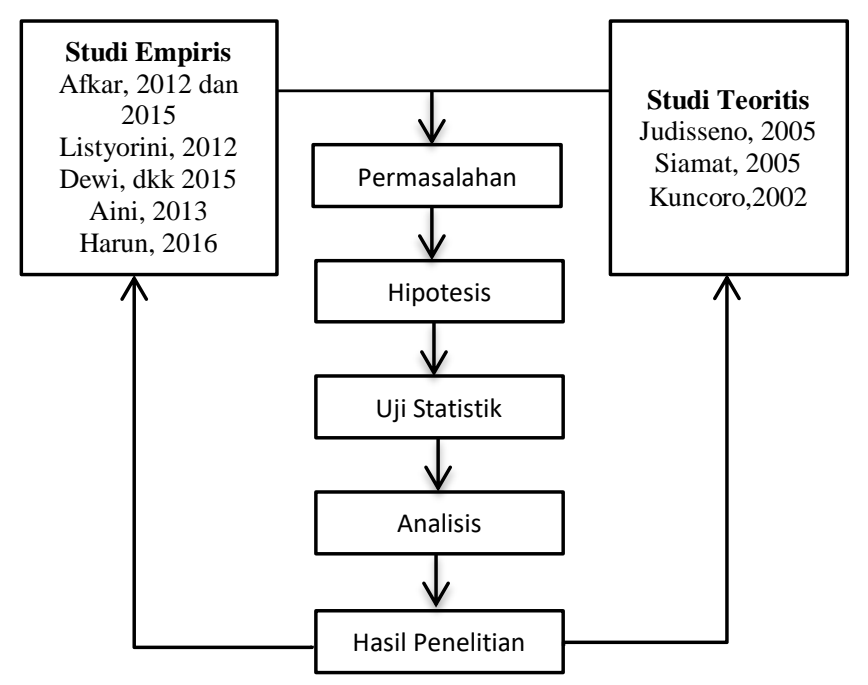

Gambar 3.2

Kerangka Berpikir

\section{Teknik Pengumpulan Data}

Penelitian ini menggunakan pendekatan kuantitatif dengan unit analisis laporan kinerja keuangan Bank Umum Syariah di Indonesia, oleh karena itu teknik pengumpulan data yang digunakan adalah dokumentasi. Dokumentasi yang dimaksud adalah data laporan kinerja keuangan yang telah diolah oleh Bank Indonesia selaku pengawas perbankan. Data yang dikumpulkan berkaitan dengan rumusan masalah yang diajukan yaitu mengenai kredit macet, kecukupan likuiditas, dan efisiensi biaya operasional.

Pengumpulan data dilakukan dengan menyesuaikan kebutuhan untuk analisis yaitu dengan menentukan unit analisisnya yaitu laporan kinerja keuangan Bank Umum Syariah di Indonesia. Pengambilan data sesuai dengan perkembangan terbaru dan menyesuaikan kebutuhan untuk uji statistik yang bersifat time series. 


\section{Teknik Analisis Data}

Teknik analisis data yang digunakan disesuaikan dengan kebutuhan dan berdasarkan data yang diperoleh. Teknik analisis data yang digunakan mencerminkan teknik yang dapat digunakan untuk menjawab rumusan masalah yang diajukan dalam penelitian ini. Rumusan masalah pada penelitian ini mempermasalahkan tentang pengaruh variabel bebas yang tediri dari 2(dua) variabel terhadap variabel terikat yang terdiri 1 (satu) varibel.

Berdasarkan rumusan masalah yang diajukan maka teknik analisis yang dapat digunakan adalah regresi linier ganda dengan 2(dua) prediktor yaitu 2(dua variabel bebebas. Untuk mengetahui pengaruh masing-masing variabel bebas sekaligus mengetahui variabel yang paling dominan pengaruhnya terhadap variabel terikat dapat dilihat pada perhitungan nilai t dengan taraf signifikansi 5\%, sedangkan untuk menegtahui secara simultan pengaruh kedua variabel bebas terhadap variabel terikat menggunakan perhitungan nila $\mathrm{F}$ sengan taraf signifikansi $5 \%$.

Selanjutnya untuk mengetahui besaran pengaruh variabel bebas terhadap variabel terikat dapat dilihat dengan perhitungan $r$ kuadrat yang sudah dilakukan penyesuaian (adjusted $r$ square).

Berdasarkan perhitungan nilai $\mathrm{t}$ dan nilai $\mathrm{F}$ dan besaran pengaruh variabel bebas terhadap variabel terikat, maka akan didapatkan persamaan dalam regresi linier ganda dengan 2(dua) prediktor.

Persamaana regresi linier ganda diperoleh $\mathrm{BOPO}=\mathrm{a}+\mathrm{b} \mathrm{NPF}+\mathrm{b}$ FDR $+\mathrm{e}$

\section{HASIL PENELITIAN DAN PEMBAHASAN \\ Hasil Penelitian}

Data yang diperoleh secara time series periode bulanan selama 3 (tiga) tahun. Data yang digunakan merupakan perhitungan laporan keuangan gabungan Bank Umum Syariah di Indonesia yang diolah oleh Bank Indonesia. Data tersebut berhubungan dengan permasalahan penelitian yaitu mengenai kredit macet, kecukupan likuiditas, dan biaya operasional pendapatan operasional yang sudah didokumentasikan dalam bentuk laporan kinerja keuangan Bank Umum Syariah.

Tabel 4.1

\section{Rekapitulasi Data}

\begin{tabular}{|l|c|c|c|c|c|c|c|c|c|}
\hline \multirow{2}{*}{ Bulan } & \multicolumn{3}{|c|}{ NPF (\%) } & \multicolumn{3}{c|}{ FDR (\%) } & \multicolumn{3}{c|}{ BOPO (\%) } \\
\cline { 2 - 11 } & $\mathbf{2 0 1 2}$ & $\mathbf{2 0 1 3}$ & $\mathbf{2 0 1 4}$ & $\mathbf{2 0 1 2}$ & $\mathbf{2 0 1 3}$ & $\mathbf{2 0 1 4}$ & $\mathbf{2 0 1 2}$ & $\mathbf{2 0 1 3}$ & $\mathbf{2 0 1 4}$ \\
\hline Januari & 2.68 & 2.49 & 3.01 & 87.27 & 100.63 & 100.07 & 86.22 & 70.43 & 80.05 \\
\hline Februari & 2.82 & 2.72 & 3.53 & 90.49 & 102.17 & 102.03 & 78.39 & 72.06 & 83.77 \\
\hline Maret & 2.76 & 2.75 & 3.12 & 87.13 & 102.62 & 102.22 & 77.77 & 72.95 & 91.90 \\
\hline April & 2.85 & 2.85 & 3.48 & 95.39 & 103.08 & 95.50 & 77.77 & 73.95 & 84.50 \\
\hline Mei & 2.93 & 2.92 & 4.02 & 97.95 & 102.08 & 99.43 & 76.24 & 76.87 & 76.49 \\
\hline Juni & 2.88 & 2.64 & 3.90 & 98.59 & 104.43 & 100.80 & 75.24 & 76.18 & 71.76 \\
\hline Juli & 2.92 & 2.75 & 4.31 & 99.91 & 104.83 & 99.89 & 75.87 & 76.12 & 79.80 \\
\hline Agustus & 2.78 & 3.01 & 4.58 & 101.03 & 102.53 & 98.99 & 75.89 & 77.82 & 81.20 \\
\hline September & 2.74 & 2.80 & 4.67 & 102.10 & 103.27 & 99.71 & 75.44 & 77.98 & 82.39 \\
\hline
\end{tabular}




\begin{tabular}{|l|l|l|l|l|l|l|l|l|l|} 
Oktober & 2.58 & 2.96 & 4.58 & 100.84 & 103.03 & 98.99 & 75.04 & 79.06 & 75.61 \\
\hline November & 2.50 & 3.08 & 4.86 & 101.19 & 102.58 & 94.62 & 75.29 & 78.59 & 93.50 \\
\hline Desember & 2.22 & 2.62 & 4.33 & 100.00 & 100.32 & 91.50 & 74.97 & 78.21 & 79.28 \\
\hline
\end{tabular}

Sumber : Bank Indonesia, diolah

\section{Analisis Data}

Analisis data yang digunakan sesuai dengan teknik analisis data yang sudah dirumuskan sebelumnya yaitu dengan menggunakan regresi linier ganda 2(dua) prediktor yaitu 2(dua) variabel bebas yang terdiri dari kredit macet $\left(\mathrm{X}_{1}\right)$ yang diukur dengan rasio Non Performing Finance (NPF) dan kecukupan likuiditas $\left(\mathrm{X}_{2}\right)$ yang diukur dengan rasio Financing to Deposits Ratio (FDR), sedangkan variabel terikat
Efisiensi Biaya Operasional (Y) yang diukur dengan menggunakan rasio BOPO.

Perhitungan nilai t untuk mengetahui pengaruh secara parsial dan sekaligus mengetahui variabel yang memiliki pengaruh yang paling dominan, sedangkan perhitungan nilai $F$ untuk mengetahui pengaruh variabel bebas terhadap variabel terikat secara simultan. Nilai adjusted $r$ square merepresentasikan besaran pengaruh kedua variabel bebas terhadap variabel terikat dalam penelitian ini.

\section{Kredit Macet Terhadap Efisiensi Biaya Operasional}

Tabel 4.2

Perhitungan nilai $t$

Coefficients $^{\mathbf{a}}$

\begin{tabular}{|c|c|c|c|c|c|c|c|c|c|c|c|c|}
\hline \multirow[b]{2}{*}{ Model } & \multicolumn{2}{|c|}{$\begin{array}{l}\text { Unstandardized } \\
\text { Coefficients }\end{array}$} & \multirow{2}{*}{$\begin{array}{c}\text { Standardiz } \\
\text { ed } \\
\text { Coefficient } \\
\mathrm{s} \\
\\
\\
\text { Beta }\end{array}$} & \multirow[b]{2}{*}{$\mathrm{t}$} & \multirow[b]{2}{*}{ Sig. } & \multicolumn{2}{|c|}{$\begin{array}{c}95.0 \% \\
\text { Confidence } \\
\text { Interval for B }\end{array}$} & \multicolumn{3}{|c|}{ Correlations } & \multicolumn{2}{|c|}{$\begin{array}{c}\text { Collinearity } \\
\text { Statistics }\end{array}$} \\
\hline & B & $\begin{array}{l}\text { Std. } \\
\text { Error }\end{array}$ & & & & $\begin{array}{l}\text { Lower } \\
\text { Bound }\end{array}$ & $\begin{array}{l}\text { Upper } \\
\text { Bound }\end{array}$ & $\begin{array}{l}\text { ord } \\
\text { er }\end{array}$ & $\begin{array}{c}\text { Parti } \\
\text { al }\end{array}$ & Part & $\begin{array}{c}\text { Tolera } \\
\text { nce }\end{array}$ & VIF \\
\hline $\begin{array}{l}1 \text { (Const } \\
\text { ant) }\end{array}$ & $\begin{array}{r}99.34 \\
5\end{array}$ & 18.008 & & $\begin{array}{r}5.51 \\
7\end{array}$ & .000 & 62.706 & $\begin{array}{r}135.98 \\
3\end{array}$ & & & & & \\
\hline NPF & 2.651 & 1.051 & .385 & $\begin{array}{r}2.52 \\
2\end{array}$ & .017 & .512 & 4.790 & $\begin{array}{r}.43 \\
1\end{array}$ & .402 & .379 & .970 & \\
\hline FDR & -.298 & .172 & -.264 & $\begin{array}{r}- \\
1.73 \\
0\end{array}$ & .093 & -.648 & .052 & $\begin{array}{r}- \\
.33 \\
1\end{array}$ & -.288 & $\begin{array}{r}- \\
.260\end{array}$ & .970 & $\begin{array}{r}1.03 \\
1\end{array}$ \\
\hline
\end{tabular}

Dependent Variable: BOPO 
Rumusan hipotesis $\mathrm{Ho}=\beta=0$ Tidak ada pengaruh Kredit Macet $\left(\mathrm{X}_{1}\right)$ terhadap Efisiensi Biaya Operasional (Y)

Rumusan hipotesis $\mathrm{H}_{\mathrm{a}}=\beta \neq 0$ Terdapat pengaruh Kredit Macet $\left(\mathrm{X}_{1}\right)$ terhadap Efisiensi Biaya Operasional (Y) dengan $\alpha=0,05$ kriteria penolakan Ho yaitu Tolak Ho jika $t_{\text {hitung }}>\mathrm{t}_{\text {tabel }}\left(\frac{\alpha}{2} ; v\right)$ sedangkan $v=n-K-1$

Berdasarkan tabel 4.2 diperoleh nilai $t_{\text {hitung }}$ pada variabel $\left(\mathrm{X}_{1}\right)$ sebesar 2.522 dengan taraf signifikansi $(\alpha) 0.017$ dan $t_{\text {tabel }}(0,025$; 33) sebesar 2.042. Rumusan hipotesis Ho yang berbunyi tidak ada pengaruh kredit macet $\left(\mathrm{X}_{1}\right)$ terhadap efisiensi biaya operasional (Y) ditolak, sedangkan hipotesis $\mathrm{H}_{\mathrm{a}}$ yang berbunyi terdapat pengaruh kredit macet $\left(\mathrm{X}_{1}\right)$ terhadap efisiensi biaya operasional (Y) diterima. Hal ini ditunjukkan dari hasil uji statistik secara parsial yang diperoleh nilai $t_{\text {hitung }}>\mathrm{t}_{\text {tabel }}(0,025 ; 33)$.

Hasil ini menunjukkan bahwa ketika terjadi kredit macet maka jumlah biaya operasional yang digunakan akan menjadi lebih banyak atau lebih besar karena ada biaya yang digunakan untuk cadangan biaya penghapusan atas pembiayaan atau kredit yang bermasalah. Hasil penelitian ini sesuai dengan Afkar, 2012, Listyorini, 2012, Dewi, dkk 201, Aini, 2013, Harun, 2016 yang menunjukkan bahwa ketika terjadi kredit bermasalah yang ditunjukan dari rasio Non Performing Finance maka yang terjadi adalah penurunan tingkat profitabilitas. Menurunnya tingkat profitabilitas ini salah satunya adalah adanya biaya yang dikeluarkan untuk penghapusan kredit yang macet atau tidak dapat diterima pembayarannya dari nasabah.

\section{Kecukupan Likuiditas Terhadap Efisiensi Biaya Operasional}

Rumusan hipotesis Ho $=\beta=0$

Tidak ada pengaruh Kecukupan Likuiditas $\left(\mathrm{X}_{2}\right)$ terhadap Efisiensi Biaya Operasional (Y)

Rumusan hipotesis $\mathrm{H}_{\mathrm{a}}=\beta \neq 0$

Terdapat pengaruh Kecukupan Likuiditas $\left(\mathrm{X}_{2}\right)$ terhadap Efisiensi Biaya Operasional (Y)

dengan $\alpha=0,05$ kriteria penolakan Ho yaitu Tolak Ho jika $t_{\text {hitung }}>\mathrm{t}_{\text {tabel }}\left(\frac{\alpha}{2} ; v\right)$ sedangkan $v=n-K-1$

Berdasarkan tabel 4.2 diperoleh nilai $t_{\text {hitung }}$ pada variabel $\left(\mathrm{X}_{2}\right)$ sebesar -1.730 dengan taraf signifikansi $(\alpha) 0.093$ dan $t_{\text {tabel }(0,025 ; 33)}$ sebesar 2.042. Rumusan hipotesis Ho yang berbunyi tidak ada pengaruh Kecukupan Likuiditas $\left(\mathrm{X}_{2}\right)$ terhadap efisiensi biaya operasional (Y) diterima, sedangkan hipotesis $\mathrm{H}_{\mathrm{a}}$ yang berbunyi terdapat pengaruh kredit macet $\left(\mathrm{X}_{2}\right)$ terhadap efisiensi biaya operasional (Y) ditolak. Hal ini ditunjukkan dari hasil uji statistik secara parsial yang diperoleh nilai $\mathrm{t}_{\text {hitung }}<\mathrm{t}_{\text {tabel }}(0,025 ; 33)$.

Hasil perhitungan ini menunjukkan bahwa kecukupan likuiditas tidak mempengaruhi efisiensi biaya karena likuiditas tidak berhubungan langsung dengan efisiensi biaya, likiuiditas sendiri merupakan jumlah pembiayaan yang diberikan dibandingkan dengan dana pihak ketiga yang dapat dihimpun sehingga kecukupan likuiditas ini berdasarkan pada jumlah dana yan dapat dihimpun. Efisiensi biaya operasional merupakan biaya yang dikeluarkan dalam rangka untuk mendapatkan laba yang diinginkan. 
Variabel Paling Dominan Berpengaruh Terhadap Efisiensi Biaya Operasional

Berdasarkan perhitungan pada tabel 4.2 yang telah dianalisis melalui dua variabel bebas NPF dan FDR menunjukkan bahwa NPF memberikan pengaruh yang signifikan terhadap efsiensi biaya operasional, sehingga ketika nilai kredit macet yang dihitung dengan rasio NPF itu tinggi maka tidak terjadi efisiensi biaya karena ada dana yang digunakan untuk cadangan penghapusan dari pembiayaan yang tidak dapat ditagih.

Kecukupan likuiditas yang dihitung dengan rasio FDR menunjukkan bahwa tidak ada pengaruh yang signifikan atau dengan kata lain variabel kecukupan likuiditas tidak berpengaruh secara langsung hal ini karena rasio FDR merupakan pembiayaan yang dilakukan oleh Bank Syariah dari dana pihak ketiga yang dihimpun sedangkan efisiensi biaya operasional lebih menekankan pada biayabiaya yang berhubungan dengan cadangan penghapusan kolektabilitas aktiva produktif serta biaya-biaya operasional lainnya.

Analisis menunjukkan bahwa variabel yang paling dominan mempengaruhi efisiensi biaya adalah variabel kredit macet atau pembiayaan bermasalah yang dihitung dengan rasio Non Performing Finance (NPF) dengan tingkat pengaruh sebesar $40.2 \%$ sedangkan kecukpan likuiditas tidak mempengaruhi efisiensi biaya secara langsung.

Tabel 4.3

Hasil Uji F

ANOVA $^{b}$

\begin{tabular}{|rl|r|r|r|r|r|}
\hline \multicolumn{2}{|l|}{ Model } & \multicolumn{1}{|c|}{$\begin{array}{l}\text { Sum of } \\
\text { Squares }\end{array}$} & df & Mean Square & F & Sig. \\
\hline 1 & Regression & 217.125 & 2 & 108.562 & 5.600 & $.008^{\mathrm{a}}$ \\
& Residual & 639.728 & 33 & 19.386 & & \\
\multicolumn{1}{|c|}{ Total } & 856.852 & 35 & & & \\
\hline
\end{tabular}

a. Predictors: (Constant), FDR, NPF

b. Dependent Variable: BOPO

Rumusan hipotesis $H_{0}=\beta_{1}=0 \beta_{2}=0$

Tidak ada pengaruh Kredit Macet $\left(\mathrm{X}_{1}\right)$ dan Kecukupan Likuiditas $\left(\mathrm{X}_{2}\right)$ terhadap Efisiensi Biaya Operasional (Y)

Rumusan hipotesis $\mathrm{H}_{\mathrm{a}}=\beta_{1} \neq 0 \quad \beta_{2} \neq 0$ Terdapat pengaruh Kredit Macet $\left(\mathrm{X}_{1}\right)$ dan Kecukupan Likuiditas $\left(\mathrm{X}_{2}\right)$ terhadap Efisiensi Biaya Operasional (Y) dengan $\alpha=0,05$ dan kriteria penolakan $\mathrm{H}_{\mathrm{o}}$ Jika $F_{\text {hitung }}>\mathrm{F}_{\text {tabel }(v 1 ; v 2)}$

Perhitungan nilai $\mathrm{F}$ pada tabel 4.3 menunjukkan tingkat signifikasi sebesar
0.008 dengan nilai $\mathrm{F}$ hitung sebesar 5.600 $>$ nilai $\mathrm{F}$ tabel 5.340. Hal ini menunjukkan bahwa secara simultan variabel kredit macet dan kecukupan likuiditas berpenaruh terhadap efisiensi biaya operasional. Kredit macet berpengaruh secara signifikan dimana pengaruh ini menunjukkan bahwa ketika terjadi kredit macet maka biaya operasional meningkat. Sedangkan kecukupan likuiditas tidak berpengaruh secara signifikan dengan menunjukkan nilai negatif, artinya bahwa 
ketika terjadi penurunan likuiditas biaya

mengalami kenaikan.

operasional yang dikeluarkan juga tidak

Tabel 4.4

Adjusted R Square

Model Summary ${ }^{b}$

\begin{tabular}{|c|c|c|c|c|c|c|c|c|c|c|}
\hline \multirow[b]{2}{*}{ Model } & \multirow[b]{2}{*}{$\mathrm{R}$} & \multirow[b]{2}{*}{$\begin{array}{c}\mathrm{R} \\
\text { Square }\end{array}$} & \multirow[b]{2}{*}{$\begin{array}{l}\text { Adjusted } \\
\text { R Square }\end{array}$} & \multirow{2}{*}{\begin{tabular}{|c|} 
Std. \\
Error of \\
the \\
Estimate
\end{tabular}} & \multicolumn{5}{|c|}{ Change Statistics } & \multirow[b]{2}{*}{$\begin{array}{l}\text { Durbin- } \\
\text { Watson }\end{array}$} \\
\hline & & & & & $\begin{array}{c}\text { R Square } \\
\text { Change }\end{array}$ & $\begin{array}{c}\mathrm{F} \\
\text { Change }\end{array}$ & df1 & df2 & $\begin{array}{c}\text { Sig. F } \\
\text { Change }\end{array}$ & \\
\hline 1 & $.503^{\mathrm{a}}$ & .253 & .208 & 4.40292 & .253 & 5.600 & 2 & 33 & .008 & 1.438 \\
\hline
\end{tabular}

a. Predictors: (Constant), FDR, NPF

b. Dependent Variable: BOPO

Hasil perhitungan pada tabel 4.4 menunjukkan adjusted $\mathrm{R}$ square sebesar $20.8 \%$. perhitungan ini menunjukkan bahwa variabel kredit macet dan kecukupan likuiditas dapat menjelaskan pengaruhnya terhadap efisiensi biaya operasional. Rendahnya persentase kedua variabel dalam penelitian ini menunjukkan bahwa kedua variabel dalam penelitian ini memiliki kemampuan yang relatif rendah dibandingkan variabel-variabel yang lain yang tidak dijelaskan dalam penelitian ini.

Variabel kredit macet dan kecukupan likuiditas hanya mampu memberikan gambaran sebesar $20.8 \%$ sedangkan sisanya sebesar $79.2 \%$ dijelaskan atau dipengaruhi variabel lain yang tidak dijelaskan dalam penelitian ini.

Persamanan regeresi dalam penelitian tentang efisiensi biaya operasional di Bank Umum Syariah di Indonesia diperoleh $\mathrm{BOPO}=9.345+$ 2.522 NPF -1.730 FDR + 18.008

\section{PENUTUP}

\section{Simpulan}

1. Kredit macet berpengaruh signifikan terhadap efisiensi biaya operasional pada bank umum syariah di Indonesia yaitu sebesar $40.2 \%$. Pengaruh yang signifikan ini menunjukkan bahwa ketika terjadi kredit macet maka biaya operasional akan meningkat sehingga tidak terjadi efisiensi biaya operasional melainkan meningkatnya biaya yang dikeluarkan akibat dari besarnya cadangan atau biaya untuk penghapusan kolektabilitas aktva produktif

2. Kecukupan likuiditas tidak berpengaruh secara signifikan karena kecukupan likuiditas tidak berkaitan langsung dengan efisiensi biaya operasional. Kecukupan likuiditas yang dihitung dengan rasio FDR tidak menunjukkan adanya pengaruh yang signifikan.

3. Variabel yang paling dominan berpengaruh terhadap efisiensi biaya operasional pada Bank Umum Syariah di Indonesia adalah kredit macet yang memiliki pengaruh sebesar $40.2 \%$ sedangakan kecukupan likuiditas berbanding terbalik dengan nilai negatif sebesar $-28.8 \%$. 
4. Secara simultan kedua variabel dapat menjelaskan pengaruhnya dengan tingkat korelasi yang berbeda dengan nilai $\mathrm{F}$ hitung sebesar 5.600 dengan tingkat signifikansi sebesar 0.008 . Variabel kredit mecet menjelaskan pengaruhnya secara positif sedangkan variabel kecukupan likuiditas menjelaskan tidak berengaruh dengan nilai negatif.

\section{Saran}

1. Bank Syariah perlu memberikan perhatian khusus terhadap adanya kredit macet dengan cara mengelola dengan baik pada saat penyaluran dana melalui pembiayaan dan penghimpunan dana melalui penagihan atas pembiayan yang telah diberikan dengan menjaga rasio pembiayaan bermasalah dibawah $5 \%$

2. Menjaga kecukupan likuiditas bank umum syariah dengan rasio maksimal $110 \%$ dari dana pihak ketiga yang dihimpun meskipun tidak berpengaruh langsung terhadap biaya operasional.

3. Variabel yang paling dominan berpengaruh terhadap efisiensi biaya operasional adalah kedit macet, oleh karena itu perlu diperhatikan pembiayaan yang bermasalah dengan memberikan pemahaman tentang pelunasan pembayaran pembiayaan sekaligus bertindak hati-hati dalam proses pembiayaan kepada nasabah agar tidak terjadi kredit macet yang berlebihan sehingga menimbulkan biaya lebih besar.

4. Pengaruh secara simultan menunjukkan bahwa kedua variabel memiliki peran yang cukup penting dalam operasional bank umum syariah di Indonesia. Oleh karena itu perlu diperhatikan pengaruhnya baik pengaruh yang sifatnya positif dan negatif karena kecukupan likuiditas dan kredit macet menunjukkan kinerja keuangan dan akan dapat membentuk opini publik terkait kesehatan keuangan bank syariah.

\section{DAFTAR PUSTAKA}

Abedifar, P., Molyneux, P., Tarazi, A. 2013. Risk in Islamic Banking. Review of Finance , 17, 2035-2096.

Afkar, Taudlikhul. 2012. Pengaruh Pembiayaan yang diberikan Terhadap Dana Pihak Ketiga pada Perbankan Syariah di Indonesia (Bank Umum Syariah dan Unit usaha Syariah). Jurnal Studi Islam An Najah, Vol. 2 No.1 September 2012

Performing Finance Terhadap Likuiditas Perbankan Syariah di Indonesia (Studi Kasus Pasca Krisis Keuangan Global). Jurnal Ekosiana. Vol.1, No.2 September 2014 2015. Pengaruh Risiko Kredit Terhadap Kecukupan Modal Perbankan Syariah di Indonesia. Jurnal Ekosiana. Vol.2, No.2 September 2015

Aini, Nur .2013. Pengaruh CAR, NIM, LDR, NPL, BOPO, dan Kualitas Aktiva Produktif Terhadap Perubahan Laba (Studi Empiris Pada Perusahaan Perbankan yang terdaftar di BEI) Tahun 2009-2011. Dinamika Akuntansi, Keuangan dan Perbankan. Mei 2013, Hal: 14 - 25 Vol. 2, No. 1

Almilia, Luciana Spica dan Herdiningtyas, Winny. 2005. Analisis Rasio CAMEL terhadap Prediksi Kondisi Bermasalah pada Lembaga Perbankan Periode 2000- 
2002.Jurnal Akuntansi dan

Keuangan. 7 (2): h: 131-147

Ambo Aman. 2013. Analisis Kinerja

Keuangan Dengan Menggunakan

Metode Camel Pada Bank Umum

Swasta Nasional Devisa Di

Indonesia Tahun 2007-2011.

UNHAS Makassar

Angbazo, L. 1997. Commercial Bank Net Interest Margin, Default Risk, Interest-Rate Risk, and Off-Balance Sheet Banking. Journal of Banking and Finance. Vol 21, Page 55-87

Bahtiar, Usman. 2003. Analisis Rasio Keuangan Dalam Memprediksi Perubahan Laba Pada Bank-Bank di Indonesia. Media Riset Bisnis

Bank Indonesia. 2010. Krisis Global dan Penyelamatan Sistem Perbankan Indonesia. Jakarta : Humas Bank Indonesia

Beck, T dkk. 2013. Islamic vs. Conventional banking: Business model, efficiency and stability. Journal of Banking and Finance. Vol. 37, Page 443-447.

Bourkhis, K., dan Nabi, M. S. 2013. Islamic And Conventional Bank's Soundness During The 2007-2008 Financial Crisis. Review of Financial Economics. Vol. 22, Page 68-77.

Dendawijaya, L. 2005. Manajemen Perbankan Edisi 2. Bogor : Ghalia Indonesia

Dewi, dkk. 2015. Analisis Pengaruh NIM, BOPO, LDR, DAN NPL Terhadap Profitabilitas (Studi Kasus Pada Bank Umum Swasta Nasional Yang Terdaftar Pada Bursa Efek Indonesia Periode 2009-2013). e-Journal S1 Akuntansi Universitas Pendidikan Ganesha Jurusan Akuntansi Program S1 Volume: 3 No. 1 Tahun 2015
Harun, Usman. 2016. Pengaruh RatioRatio Keuangan CAR, LDR, NIM, BOPO, NPL Terhadap ROA. Jurnal Riset Bisnis dan Manajemen, Vol 4,No.1, 2016: 67-82

Hasan, Maher dan Dridi, Jemma. 2010. The Effects of The Global Crisis on Islamic and Conventional Banks : A Comparative Study. IMF Working Paper WP/10/201

Judisseno, Rimsky K. 2005. Sistem Moneter dan Perbankan di Indonesia. Jakarta : PT. Gramedia Pustaka Utama.

Kuncoro, Mudrajad dan Suhardjono. 2002. Manajemen Perbankan Teori dan Aplikasi. Yogyakarta : BPFE UGM

Listyorini Wahyu Widati. 2012. Analisis Pengaruh Camel Terhadap Kinerja Perusahaan Perbankan Yang Go Publik (analysis the influence of camel (car, ppap, der, bopo, ldr) toward performance of banking companies in indonesia). Dinamika Akuntansi, Keuangan dan Perbankan, Nopember 2012, Hal: 105 - 119 Vol. 1, No. 2

Muhammad. 2005. Manajemen Perbankan Syariah. Yogyakarta: UUP AMPY KPN

Olson, Irwin. D. Dan Zoubi,T.A. 2008. Using accounting ratios to distinguish between Islamic and conventional banks in the GCC region. The International Journal of Accounting, 43, 45-65.

Rajhi, W. 2012. Islamic Banks and Financial Stability: A Comparative Empirical Analysis between MENA and Southeast Asian Countries. Laboratory of Economics Applied to Development (LEAD). University of Toulon-Var, May 1, 2012. Available at 
http://papers.ssrn.com/sol3/papers.cf m?abstract_id $=2010126$. Access 2015

Siamat, Dahlan. 2005. Manajemen Lembaga keuangan. Edisi 4. Jakarta : Badan penerbit Fakultas Ekonomi Universitas Indonesia

Sutojo, Siswanto. 2008. Seri Manajemen Perbankan No.6 - Strategi Manajemen Kredit Perbankan Umum : Konsep, Teknik dan Kasus. Jakarta : Damar Mulia Pustaka. 